\title{
ANALISIS TINGKAT KESEHATAN BANK UMUM SYARIAH SEBELUM DAN SESUDAH TERDAFTAR DI BEI
}

\author{
Yetri Martika Sari \\ ${ }^{1}$ Fakultas Ekonomi dan Bisnis Islam,Universitas Islam Negeri Raden Intan, Lampung \\ e-mail: yetri.martika@,radenintan.ac.id
}

\begin{abstract}
This study aims to assess the soundness of sharia commercial banks before and after being registered on the Indonesian stock exchange using the Risk-Based Bank Rating (RBBR) method which is stipulated in the OJK regulation No.8/POJK.03/2014 concerning the assessment of the soundness level of sharia commercial banks and sharia business units. The object of this research are sharia commercial banks registered on the Indonesian stock exchange (IDX). The sampling technique in this study used purposive sampling with the criteria of sharia commercial banks which was conducting an initial public offering in 2018. Two samples were obtained for this research, namely BRIS and BTPNS. The analytical techniques in this study were descriptive quantitative using four RBBR factors namely risk profile (NPF and FDR), GCG, profitability (NOM and ROA), and capital (CAR). The results of this study on the soundness of the bank before and after being listed on the IDX did not indicate a difference in the health rating of the banks both BRIS and BTPNS. the results of a comparison of the performance of BRIS and BTPNS seen from the four RBBR factors showed that BTPNS's performance was better than BRIS's performance.
\end{abstract}

Keywords:Bank Soundness Rating, RBBR, Sharia Commercial Bank

\section{PENDAHULUAN}

Undang-undang No.10 Tahun 1998 membagi bank menjadi Bank Umum dan Bank Perkreditan Rakyat. Bank Umum adalah bank yang melaksanakan kegiatan usaha secara konvensional dan atau berdasarkan prinsip syariah yang dalam kegiatannya memberikan jasa dalam lalu lintas pembayaran. Bank Perkreditan Rakyat adalah bank yang melaksanakan kegiatan usaha secara konvensional atau berdasarkan prinsip Syariah yang dalam kegiatannya tidak memberikan jasa lalu lintas pembayaran.Bank umum yang melaksanakan kegiatan usaha berdasarkan prinsip Syariah dikenal dengan nama Bank Umum Syariah (BUS).Bank merupakan bisnis kepercayaan, sehingga untuk mendapatkan kepercayaan dari masyarakat Bank harus mampu memberikan keyakinan bahwa Bank merupakan tempat yang aman untuk menyimpan dan meminjam dana. Salah satu cara untuk memberikan keyakinan masyarakat tersebut adalah dengan menjaga tingkat kesehatan Bank.

Terkait hal tersebut Otoritas Jasa Keuangan (OJK) menetapkan Peraturan Otoritas Jasa Keuangan Nomor 08/POJK.03/2014 untuk menilai tingkat kesehatan Bank Umum Syariah (BUS) dan Unit Usaha Syariah (UUS). Sesuai peraturan tersebut, bank wajib melakukan penilaian sendiri (self-assessment) atas tingkat kesehatan bank dengan metode riskbased bank rating(RBBR). Penilaian tingkat kesehatan bank dengan metode risk-based bank rating mencakup beberapa faktor, antara lain profil risiko (risk profile), good corporate governance (GCG), rentabilitas (earnings), dan permodalan (capital). 
Sebelum menggunakan RBBR, Bank Indonesia menetapkan sistem penilaian tingkat kesehatan Bank berbasis risiko menggunakan metode Capital, Asset Quality, Management, Earnings, Liquidity, Sensitivity to Market Risk (CAMELS). Evaluasi kinerja menggunakan CAMELS dianggap masih terfokus pada pencapaian laba dan pertumbuhan bank, hanya sedikit yang membahas sisi risiko. Evaluasi yang hanya fokus pada laba dan pertumbuhan bankcenderung bias dan tidak berorientasi pencapaian jangka Panjang.Penilaian kesehatan bank menggunakan RBBR, menekankan bahwa tingkat kesehatan bank, pengelolaan bank dan operasi bisnis yang dijalankan oleh bank sepenuhnya merupakan tanggung jawab bank (Pambudi, 2018).

Perubahan metode penilaian tingkat kesehatan Bank ini seiring dengan perkembangan dan perubahan kompleksitas usaha perbankan. Perkembangan Bank Umum Syariah (BUS) diawali dengan diberlakukannya Undang-undang No.21 Tahun 2008 tentang Perbankan Syariah. Adanya landasan hukum yang memadai menjadi salah satu faktor pendorong pertumbuhan yang lebih cepat. Pertumbuhan BUS terlihat dalam empat tahun terakhir (2015-2018), dimana pertumbuhan asset BUS dari Rp213.423 Milyar pada tahun 2015 menjadi Rp316.691 Milyar pada tahun 2018, dengan kata lain pertumbuhan asset BUS dalam empat tahun terakhir mencapai lebih dari 48\%. Jumlah BUS pun menunjukkan pertumbuhan dari 12 BUS di tahun 2015 menjadi 14 BUS di tahun 2018. Berikut data total asset BUS dan perkembangan jumlah BUS di Indonesia.

Tabel 1

Total Aset dan Jumlah Bank Umum Syariah

\begin{tabular}{ccc}
\hline Tahun & $\begin{array}{c}\text { Total Aset } \\
\text { (dalam Milyar) }\end{array}$ & Jumlah Bank \\
\hline 2015 & 213.423 & 12 \\
2016 & 254.184 & 13 \\
2017 & 288.027 & 13 \\
2018 & 316.691 & 14 \\
\hline
\end{tabular}

Sumber: Statistik Perbankan Syariah Desember (2018)

Adanya pertumbuhan BUS baik dari total asset maupun jumlah BUS di Indoensia menunjukkan bahwa Bank Syariah semakin berkembang,yang diiringi dengan meningkatnya persaingan antar BUS, bahkan BUS juga harus mampu bersaing dengan Bank Umum Konvensional. Upaya yang dilakukan BUS untuk dapat bersaing dengan Bank Umum Konvensional ditandai dengan mulai terdaftarnya beberapa BUS di Bursa Efek Indonesia (BEI). Berikut daftar BUS yang sudah terdaftar di BEI.Sampai dengan April 2019 tercatat ada tiga BUS yang sudah terdaftar di BEI, yaitu PT. Bank Panin Dubai Syariah, PT. Bank Tabungan Pensiunan Nasional Syariah (BTPNS), dan PT. BRI Syariah (BRIS), seperti tersaji pada Tabel 2.

Tabel 2

Daftar Bank Umum Syariah yang Terdaftar di BEI

\begin{tabular}{clc}
\hline No. & \multicolumn{1}{c}{ Nama BUS } & Tahun Terdaftar \\
\hline 1. & Bank Panin Dubai Syariah & 15 Januari 2014 \\
2. & PT. Bank Tabungan Pensiunan Nasional Syariah & 08 Mei 2018 \\
3. & PT. BRI Syariah & 09 Mei 2018 \\
\hline
\end{tabular}

Sumber: Bursa Efek Indonesia (2019) 
Total asset dari ketiga BUS tersebutpada tahun 2015 sampaitahun 2018 menunjukkan peningkatan yang signifikan yaitu dari Rp36.560.681 Juta di tahun 2015 menjadi Rp58.725.417 Juta di tahun 2018, sehingga kenaikan asset ketiga BUS tersebut dalam empat tahun sebesar 61\%. Sementara jika dilihat dari laba, tahun 2017 menunjukkan laba bernilai negatif, sehingga terindikasi ada kerugian yang dialami oleh BUS. Namun di tahun 2018 ketiga akumulasi laba dari ketiga BUS tersebut menunjukkan kenaikan, bahkan mencapai angka paling tinggi dalam empat tahun terakhir, yaitu sebesar Rp1.131.351 Juta.

Tabel 3

Total Aset dan Total Laba BUS yang Terdaftar di BEI

\begin{tabular}{lllll}
\hline Dalam juta rupiah & 2015 & 2016 & 2017 & 2018 \\
\hline Total Aset & $36,560,681$ & $43,768,499$ & $49,329,181$ & $58,725,417$ \\
Total Laba & 373,735 & 619,976 & $-196,378$ & $1,131,351$ \\
\hline
\end{tabular}

Sumber: Data diolah (2019)

Secara teoritis peningkatan yang terjadi pada asset maupun laba BUS tentu menjadi salah satu harapan ketika BUS memutuskan untuk melakukan IPO (Initial Public Offering) di pasar modal. Namun kinerja BUS tidak hanya dilihat dari nilai aset dan laba yang semakin meningkat saja, ada indikator lain yang harus dilihat dalam menilai kinerja bank yaitutingkat kesehatan BUS.

Penelitian sebelumnya tentang penilaian tingkat kesehatan bank dengan metode RBBR dilakukan oleh Dea Amelia, Zahroh, dan Devi (2017) dimana penelitian tersebut dilakukan pada bank konvensional milik pemerintah yang terdaftar di BEI dan hanya membahas mengenai risiko kredit, risiko pasar, risiko likuiditas, dan permodalan. Hasil penelitian tersebut bahwa NPL rata-rata bank konvensional milik pemerintah dibawah $5 \%$, ROA dan NIM menunjukkan rata-rata rentabilitas yang sangat memadai, dan CAR menunjukkan seluruh sampel berpredikat sangat sehat. Penelitian lain tentang penilaian tingkat kesehatan bank dilakukan oleh Setyo Pambudi dan Ari Darmawan (2018) dengan objek penelitian pada BUS yang terdaftar di OJK. Kelemahan dalam penelitian ini adalah meskipun objek yang diteliti adalah BUS namun dalam menganalisa menggunakan peraturan OJK untuk menilai tingkat kesehatan bank konvensional.

Berdasarkan uraian tersebut penelitian ini dilakukan untuk mengetahui perbedaan tingkat kesehatan BUS sebelum dan sesudah terdaftar di BEI pada BRIS dan BTPNS dengan menggunakan metode RBBR. Pemilihan BRIS dan BTPNSsebagai objek penelitiandikarenakan proses IPO dilakukan pada tahun yang sama yaitu 2018.Dalam menganalisa tingkat kesehatan bank penelitian ini hanya melihat dari aspek kuantitatif dari setiap faktor dalam RBBR dengan mengacu pada peraturan OJK Nomor 8/POJK.03/2014, surat edaran OJK Nomor 10/SEOJK.03/2014 dan kodifikasi Bank Indonesia tahun 2012 terkait penilaian tingkat kesehatan BUS.Penelitian ini diharapkan dapat memberikan masukan kepada manajemen terkait kondisi kesehatan BUS sebelum dan sesudah terdaftar di BEI dan diharapkan dapat berguna dalam pengambilan keputusan investasi.

\section{LITERATURE REVIEW}

\section{Tingkat Kesehatan Bank}

Tingkat kesehatan bank adalah kemampuan suatu bank untuk melakukan kegiatan operasional perbankan secara normal dan mampu memenuhi semua kewajibannnya dengan 
baik dengan cara-cara yang sesuai dengan peraturan perbankan yang berlaku (Suhartono,et.al, 2017). Undang-undang Nomor 21 Tahun 2008 tentang Perbankan Syariah menyatakan Bank Umum Syariah (BUS) wajib memelihara tingkat kesehatannya untuk menjaga kepercayaan masyarakat. Ditambahkan dalam Penjelasan POJK Nomor 8/POJK.03/2014 bahwa kesehatan bank digunakan sebagai salah satu sarana dalam melakukan evaluasi terhadap kondisi dan permasalahan yang dihadapi Bank serta menentukan tindak lanjut untuk mengatasi kelemahan atau permasalahan Bank, baik corrective action oleh Bank maupun supervisory action oleh Otoritas Jasa Keuangan (OJK) selaku wakil pemerintah dalam melakukan pengawasan terhadap Bank.

Pentingnya penilaian tingkat kesehatan Bank dikarenakan perkembangan usaha Bank bersifat dinamis dan berpengaruh pada tingkat risiko yang dihadapi, oleh karena itu tingkat kesehatan bank yang merupakan cerminan kondisi dan kinerja Bank harus disajikan secara transparan kepada masyarakat umum. Keterbukaan kondisi dan kinerja perbankan menjadi kepentingan semua pihak terkait baik pemilik, manajemen, dan masyarakat.

Peraturan Otoritas Jasa Keuangan Nomor 8/POJK.03/2014 Tentang Penilaian Tingkat Kesehatan Bank Umum Syariah dan Unit Usaha Syariahmengelompokkan kondisi bank ke dalam beberapa kategori peringkat komposit berikut:

1. Peringkat Komposit 1 (PK-1)

PK-1 artinya kondisi bank secara umum sangat sehat, sehingga dinilai sangat mampu menghadapi pengaruh negatif yang signifikan dari perubahan kondisi bisnis dan faktor eksternal lainnya.

2. Peringkat Komposit 2 (PK-2)

PK-2 artinya kondisi bank secara umum sehat, sehingga dinilai mampu menghadapi pengaruh negatif yang signifikan dari perubahan kondisi bisnis dan faktor eksternal lainnya.

3. Peringkat Komposit 3 (PK-3)

PK-3 artinya kondisi bank secara umum cukup sehat, sehingga dinilai cukup mampu menghadapi pengaruh negatif yang signifikan dari perubahan kondisi bisnis dan faktor eksternal lainnya.

4. Peringkat Komposit 4 (PK-4)

PK-4 artinya kondisi bank secara umum kurang sehat, sehingga dinilai kurang mampu menghadapi pengaruh negatif yang signifikan dari perubahan kondisi bisnis dan faktor eksternal lainnya.

5. Peringkat Komposit 5 (PK-5)

PK-5 artinya kondisi bank secara umum tidak sehat, sehingga dinilai tidak mampu menghadapi pengaruh negatif yang signifikan dari perubahan kondisi bisnis dan faktor eksternal lainnya.

\section{Risk-Based Bank Rating (RBBR)}

Peraturan OJK Nomor 8/POJK.03/2014 Tentang Penilaian Tingkat Kesehatan Bank Umum Syariah dan Unit Usaha Syariah menyatkan bahwa tingkat kesehatan bankmerupakan hasil penilaian kondisi Bank yang dilakukan berdasarkan risiko termasuk risiko terkait penerapan prinsip Syariah dan kinerja bank atau disebut dengan Risk-based Bank Rating. Definisi tersebut menekankan bahwa untuk penilaian tingkat kesehatan bank harus dilakukan dengan pendekatan berdasarkan risiko (Risk-based Bank Rating).

Risk-based Bank Rating(RBBR) dirancang sebagai metode penilaian yang terstruktur dan komprehensif terhadap hasil integrasi profil risiko (risk profile) dan kinerja yang meliputi 
penerapan tata kelola yang baik (Good Corporate Governance), rentabilitas (earnings), dan permodalan (capital).

\section{Risk Profile}

Dijelaskan dalam SE OJK Nomor 10/SEOJK.03/2014 bahwa penilaian faktor profil risiko merupakan penilaian terhadap risiko inheren dan kualitas penerapan manajemen risiko dalam operasional bank yang mencakup sepuluh risiko, yaitu risiko kredit, risiko pasar, risiko likuiditas, risiko operasional, risiko hukum, risiko stratejik, risiko kepatuhan, risiko reputasi risiko imbal hasil dan risiko investasi.Karena adanya keterbatasan data, untuk keperluan penelitian ini risk profilehanya akan diukur melalui dua indikator yaitu risiko kredit dan risiko likuiditas

1. Risiko Kredit

Risiko kredit adalah risiko akibat kegagalan nasabah dalam memenuhi kewajiban kepada Bank sesuai dengan perjanjian yang disepakati. Dalam menilai risiko kredit ada beberapa parameter/indikator yang digunakan. Dalam penelitian ini indikator yang digunakan untuk mengukur risiko kredit adalah Non-Performing Financing (NPF). Rasio NPF dipilih karena dapat mencerminkan kualitas pembiayaan pada BUS. Penetapan peringkat risiko kredit berdasarkan NPF yang disajikan pada Tabel 4 menunjukkan bahwa semakin kecil rasio NPF maka kualitas penerapan manajemen risiko kredit semakin memadai.

Tabel 4

Kriteria Penilaian Peringkat NPF

\begin{tabular}{ccc}
\hline Peringkat & Rasio & Kriteria \\
\hline 1 & $\mathrm{NPF}<2 \%$ & Strong / Sangat Memadai \\
2 & $2 \% \leq \mathrm{NPF} \leq 5 \%$ & Satisfactory / Memadai \\
3 & $5 \% \leq \mathrm{NPF} \leq 8 \%$ & Fair / Cukup Memadai \\
4 & $8 \% \leq \mathrm{NPF} \leq 12 \%$ & Marginal / Kurang Memadai \\
5 & $\mathrm{NPF} \geq 12 \%$ & Unsatisfactory / Tidak Memadai
\end{tabular}

Sumber:Kodifikasi Peraturan BI Kelembagaan Penilaian Tingkat Kesehatan Bank (2012)

2. Risiko Likuiditas

Risiko likuiditas adalah risiko akibat ketidakmampuan bank untuk memenuhi kewajiban yang jatuh tempo dari sumber pendanaan arus kas dan/ atau asset likuid yang dapat diagunkan, tanpa mengganggu aktivitas dan kondisi keuangan bank. Indikator yang digunakan untuk mengukur risiko likuiditas dalam penelitian adalahFinancing to Deposit Ratio (FDR). Penetapan peringkat risiko likuiditas berdasarkan FDRseperti pada Tabel 5 menunjukkan bahwa semakin kecil rasio FDR maka kualitas manajemen risiko likuiditas pada BUS semakin memadai.

Tabel 5

Kriteria Penilaian Peringkat FDR

\begin{tabular}{ccc}
\hline Peringkat & Rasio & Kriteria \\
\hline 1 & $50 \%<$ FDR $\leq 75 \%$ & Strong / Sangat Memadai \\
2 & $75 \%<$ FDR $\leq 85 \%$ & Satisfactory / Memadai \\
3 & $85 \%<$ FDR $\leq 100 \%$ & Fair / Cukup Memadai \\
4 & $100 \%<$ FDR $\leq 120 \%$ & Marginal / Kurang Memadai \\
5 & FDR $>120 \%$ & Unsatisfactory / Tidak Memadai \\
\hline
\end{tabular}



(2012)

\section{Good Corporate Governance(GCG)}

Penetapan peringkat faktor GCG merupakan penilaian terhadapmanajemen Bank Umum Syariah atas beberapa indikator berikut:

1. Pelaksanaan prinsip-prinsip GCG yang meliputi transparansi, akuntabilitas, pertanggungjawaban, professional, dan kewajaran

2. Kecukupan tata kelola (governance) atas aspek struktur (structure), prosesprocess) dan hasil (outcome) penerapan GCGpada BUS

3. Informasi lainnya yang terkait dengan GCG yang didasarkan pada data dan informasi yang relevan.

Sesuai peraturan OJK Nomor 8/POJK.03/2014 Tentang Penilaian Tingkat Kesehatan Bank Umum Syariah dan Unit Usaha Syariah bahwa BUS berkewajiban untuk melakukan penilaian sendiri pelaksanaan GCG secara berkala sesuai dengan periode penilaian tingkat kesehatan bank. Oleh karena itu terkait penelitian ini peringkat GCG BUS menggunakan data hasil penilaian sendiri yang dilakukan oleh BUS dan sudah di publikasikan.

Tabel 6

Kriteria Penilaian Peringkat GCG

\begin{tabular}{ccc}
\hline Peringkat & Nilai & Kriteria \\
\hline 1 & GCG $<1.5$ & Sangat Baik \\
2 & $1.5<$ GCG $\leq 2.5$ & Baik \\
3 & $2.5<$ GCG $\leq 3.5$ & Cukup Baik \\
4 & $3.5<$ GCG $\leq 4.5$ & Kurang Baik \\
5 & GCG $>4.5$ & Tidak Baik \\
\hline
\end{tabular}

Sumber:Kodifikasi Peraturan Bank Indonesia Kelembagaan Penilaian Tingkat Kesehatan Bank (2012)

Berdasarkan Penilaian peringkat GCG pada Tabel di atas disimpulkan bahwa semakin kecil hasil nilai perhitungan GCG maka semakin baik manajemen bank melakukan penerapan GCG.

\section{Rentabilitas (Eamings)}

Penilaian faktor rentabilitas meliputi evaluasi kinerja rentabilitas, sumber-sumber rentabilitas, manajemen rantabilitas, kesinambungan rentabilitas dan pelaksanaan fungsi sosial. Pada penelitian ini rentabilitas diukur menggunakan dua indikator yaitu Net Operation Margin (NOM) dan Return On Asset (ROA).

1. Net Operation Margin (NOM)

NOM merupakan rasio utama rentabilitas pada bank syariah digunakan untuk mengetahui kemampuan aktiva produktif BUS dalam menghasilkan laba dengan membandingkan antara pendapatan operasional dan beban operasional dengan rata-rata aktiva produktif.Berdasarkan penetapan peringkat NOM seperti yang ditampilkan pada Tabel 7 diperoleh kesimpulan bahwa semakin tinggi nilai NOM maka rentabilitas semakin memadai, laba melebihi target dan mendukung permodalan bank. 
Tabel 7

Kriteria Penilaian Peringkat NOM

\begin{tabular}{ccc}
\hline Peringkat & Rasio & Kriteria \\
\hline 1 & $\mathrm{NOM}>3 \%$ & Sangat Memadai \\
2 & $2 \%<\mathrm{NOM} \leq 3 \%$ & Memadai \\
3 & $1.5 \%<\mathrm{NOM} \leq 2 \%$ & Cukup Memadai \\
4 & $1 \%<\mathrm{NOM} \leq 1.5 \%$ & Kurang Memadai \\
5 & $\mathrm{NOM} \leq 1 \%$ & Tidak Memadai \\
\hline
\end{tabular}

Sumber:Kodifikasi Peraturan Bank Indonesia Kelembagaan Penilaian Tingkat Kesehatan Bank (2012)

\section{Return On Asset (ROA)}

ROA merupakan rasio penunjang penilaian rentabilitas digunakan untuk mengukur keberhasilan manajemen dalam menghasilkan laba.Pengkategorian peringkat ROA disajikan pada Tabel 8. Berdasarkan Tabel 8 disimpulkan bahwa semakin tinggi nilai ROA maka rentabilitas semakin memadai, laba melebihi target dan mendukung permodalan bank.

Tabel 8

Kriteria Penilaian Peringkat ROA

\begin{tabular}{ccc}
\hline Peringkat & Rasio & Kriteria \\
\hline 1 & $\mathrm{ROA}>1.5 \%$ & Sangat Memadai \\
2 & $1.25 \%<\mathrm{ROA} \leq 1.5 \%$ & Memadai \\
3 & $0.5 \%<\mathrm{ROA} \leq 1.25 \%$ & Cukup Memadai \\
4 & $0 \%<\mathrm{ROA} \leq 0.5 \%$ & Kurang Memadai \\
5 & $\mathrm{ROA} \leq 0 \%$ & Tidak Memadai \\
\hline
\end{tabular}

Sumber:Kodifikasi Peraturan Bank Indonesia Kelembagaan Penilaian Tingkat Kesehatan Bank

\section{Permodalan (Capita)}

Penilaian faktor permodalan meliputi evaluasi terhadap kecukupan modal dan kecukupan pengelolaan permodalan. BUS dalam melakukan perhitungan permodalan mengacu pada ketentuan yang berlaku mengenai kewajiban penyediaan modal minimum bagi BUS. Penilaian kuantitatif permodalan BUS pada penelitian ini menggunakan rasio Capital Adequacy Ratio (CAR) yang berfungsi untuk mengukur kecukupan pemenuhan kewajiban penyediaan modal minimum sesuai dengan ketentuan yang berlaku. Peringkat kriteria penilaian CAR pada Tabel 9 menunjukkan bahwa semakin tinggi rasio CAR maka BUS memiliki kualitas dan kecukupan permodalan yang semakin memadai.

Tabel 9

Kriteria Penilaian Peringkat CAR

\begin{tabular}{ccc}
\hline Peringkat & Rasio & Kriteria \\
\hline 1 & ROA $>1.5 \%$ & Sangat Memadai \\
2 & $1.25 \%<$ ROA $\leq 1.5 \%$ & Memadai \\
\hline
\end{tabular}




\begin{tabular}{ccc}
\hline 3 & $0.5 \%<\mathrm{ROA} \leq 1.25 \%$ & Cukup Memadai \\
4 & $0 \%<\mathrm{ROA} \leq 0.5 \%$ & Kurang Memadai \\
5 & $\mathrm{ROA} \leq 0 \%$ & Tidak Memadai \\
\hline $\begin{array}{c}\text { Sumber:Kodifikasi Peraturan Bank Indonesia Kelembagaan Penilaian Tingkat Kesehatan Bank } \\
\text { (2012) }\end{array}$
\end{tabular}

\section{METODE PENELITIAN}

Penelitian ini bersifat event study yaitu terjadinya peristiwa IPO atau terdaftarnya BUS di BEI. Populasi dalam penelitian ini adalah semua BUS yang terdaftar di BEI, yaitu PT. Bank Panin Dubai Syariah, PT. Bank Tabungan Pensiunan Nasional Syariah, dan PT. BRI Syariah. Sampel dipilih menggunakan teknik purposive samplingdengan kriteria yang digunakan dalam menentukan sampel adalah BUS yang melakukan initial public offering (IPO) di tahun 2018. Dari teknik tersebut diperoleh dua Bank yang menjadi sampel penelitian, yaitu PT. Bank Tabungan Pensiunan Nasional Syariah (BTPNS) dan PT. BRI Syariah (BRIS).

Sumber data dalam penelitian ini adalah data sekunder yaitu data yang diperoleh secara tidak langsung atau data yang sudah dipublikasikan. Data yang digunakan dalam penelitian ini adalah laporan keuangan triwulan BUSperiode Triwulan 2 (Q2) tahun 2017 sampai dengan triwulan 1(Q1) tahun 2019. Teknik pengumpulan data yang digunakan untuk penelitian ini adalah teknik dokumentasi. Teknik dokumentasi merupakan pencatatan data secara sistematis yang berkaitan dengan penelitian, kemudian data yang telah dikumpulkan dari berbagai sumber dipilih kembali sesuai dengan kebutuhan peneliti. Data dalam penelitian ini data diperoleh dari website resmi setiap bank dan website Bursa Efek Indonesia (BEI).

Jenis penelitian ini adalah deskriptif kuantitatif.Oleh karena itu untuk memperoleh hasil yang mendalam terkait tingkat kesehatan bank sebelum dan sesudah terdaftar di BEI maka analisis dilakukan dengantahapan sebagai berikut:

1. Menganalisisaspek kuantitatif tingkat kesehatan BRISdan BTPNS denganmetodeRisk Based Bank Rating (RBBR) menggunakan laporan keuangan triwulanan, yaitu empat triwulan sebelum terdaftar di BEI dan empat triwulan sesudah terdaftar di BEI.

2. Membandingkan aspek kauntitatif tingkat kesehatan BRIS dan BTPNS sebelum dan sesudah terdaftar di BEI

\section{HASIL PENELITIAN}

\section{Tingkat Kesehatan Bank Rakyat Indonesia Syariah (BRIS)}

Tabel 10

Tingkat Kesehatan BRIS Sebelum Terdaftar di BEI 


\begin{tabular}{|l|r|r|r|r|r|r|}
\hline \multirow{2}{*}{ BRIS } & \multicolumn{7}{|c|}{ SEBELUM } \\
\cline { 2 - 7 } & Q2-2017 & Q3-2017 & Q4-2017 & Q1-2018 & Rata-rata & Peringkat \\
\hline RISK PROFILE & $4.82 \%$ & $4.82 \%$ & $6.43 \%$ & $4.92 \%$ & $5.25 \%$ & 3 \\
\hline NPF & $76.79 \%$ & $73.12 \%$ & $71.87 \%$ & $68.70 \%$ & $72.62 \%$ & 1 \\
\hline FDR & 2 & 2 & 2 & 2 & 2 & 2 \\
\hline GCG & $0.71 \%$ & $0.82 \%$ & $0.51 \%$ & $0.86 \%$ & $0.73 \%$ & 3 \\
\hline EARNINGS & $0.25 \%$ & $0.28 \%$ & $-0.12 \%$ & $0.34 \%$ & $0.19 \%$ & 5 \\
\hline ROA & \multicolumn{7}{|c|}{} \\
\hline CAPITAL & $20.38 \%$ & $20.96 \%$ & $20.05 \%$ & $23.95 \%$ & $21.34 \%$ & 1 \\
\hline CAR & TINGKAT KESEHATAN BANK & 3 \\
\hline
\end{tabular}

Sumber: Data Diolah (2019)

Hasil perhitungan tingkat kesehatan BRIS sebelum terdaftar di BEI mendapatkan peringkat komposit 3 seperti terlihat dari tabel diatas.Peringkat Komposit 3 (PK-3) mencerminkan kondisi Bank yang secara umum cukup sehat sehingga dinilai cukup mampu menghadapi pengaruh negatif yang signifikan dari perubahankondisi bisnis dan faktor eksternal lainnya.NPF yang mencerminkan risiko kredit BRIS selama empat triwulan terakhir sebelum terdaftar di BEI mengalami fluktuatif.Rata-rata rasio NPF menunjukkan nilai sebesar $5.25 \%$ atau berada pada peringkat 3, yang artinya kualitas penerapan manajemen risiko kredit cukup memadai dan membutuhkan perhatian manajemen. Ratarata FDR sebesar $72.62 \%$ dikategorikan ke dalam peringkat 1 yang artinya tingkat likuiditas BRIS sangat sehat. Dari sisi GCG mencerminkan manajemen BRIS telah melakukan penerapan GCG yang secara umum baik. Kategori baik tercermin dari pemenuhan yang cukup memadai atas prinsip-prinsip Good Corporate Governance.Rentabilitas BRIS dilihat dari ROA sebesar $0.73 \%$ atau dikategorikan dalam peringkat 3 yang artinya keberhasilan manajemen dalam menghasilkan laba cukup memadai. Rentabilitas BRIS dilihat dari NOM berada dalam peringkat 5 yang artinya kemampuan aktiva produktif dalam menghasilkan laba tidak memadai, laba tidak memenuhi target dan tidak dapat diandalkan serta memerlukan peningkatan kinerja laba segera untuk kelangsungan usaha bank. Permodalan BRIS yang dilihat dari rasio CAR berada pada peringkat 1 yang artinya BRIS memiliki kualitas dan kecukupan permodalan yang sangat memadai.

Tingkat kesehatan BRIS sesudah terdaftar di BEI tidak menunjukkan peningkatan, tetap berada pada peringkat komposit 3 seperti terlihat padaTabel 11.Berdasarkan tabel tersebut terlihat bahwa beberapa indikator tingkat kesehatan BRIS sesudah terdaftar di BEI tidak mengalami perubahan, antara lain NPF, GCG, ROA, NOM dan CAR, hanya rasio FDR yang mengalami perubahan dari peringkat 1 sebelum terdaftar di BEI menjadi peringkat 2 sesudah terdaftar di BEI. Hal ini menunjukkan bahwa likuiditas BRIS sesudah terdaftar di BEI mengalami penurunan dari kategori sangat sehat menjadi kategori sehat.

Tabel11

Tingkat Kesehatan BRIS Sesudah Terdaftar di BEI 


\begin{tabular}{|c|r|r|r|r|r|r|}
\hline \multirow{2}{*}{ BRIS } & \multicolumn{7}{|c|}{ SESUDAH } \\
\cline { 2 - 7 } & Q2-2018 & Q3-2018 & Q4-2018 & Q1-2019 & Rata-rata & Peringkat \\
\hline RISK PROFILE & $5.13 \%$ & $5.30 \%$ & $6.73 \%$ & $5.68 \%$ & $5.71 \%$ & 3 \\
\hline NPF & $77.78 \%$ & $76.40 \%$ & $75.49 \%$ & $79.55 \%$ & $77.31 \%$ & 2 \\
\hline FDR & 2 & 2 & 2 & & 2 & 2 \\
\hline EARNINGS & $0.92 \%$ & $0.77 \%$ & $0.43 \%$ & $0.43 \%$ & $0.64 \%$ & 3 \\
\hline ROA & $0.42 \%$ & $0.10 \%$ & $-0.27 \%$ & $-0.97 \%$ & $-0.18 \%$ & 5 \\
NOM & \multicolumn{7}{|c|}{} \\
\hline CAPITAL & $29.31 \%$ & $29.79 \%$ & $29.72 \%$ & $27.82 \%$ & $29.16 \%$ & 1 \\
\hline CAR & TINGKAT KESEHATAN BANK & 3 \\
\hline
\end{tabular}

Sumber: Data diolah (2019)

Meskipun secara peringkat tingkat kesehatan BRIS sebelum dan sesudah terdaftar di BEI menunjukkan peringkat yang sama, yaitu pada peringkat komposit (PK-3) namun jika dilihat secara rasio, ada beberapa rasio yang mengalami kenaikan yang artinya kinerja menjadi lebih baik ataupun rasio yang mengalami penurunan yang artinya kinerja tidak lebih baik dari sebelum terdaftar di BEI. Sementara untuk GCG mempunyai peringkat yang stabil di peringkat 2. Rasio CAR merupakan rasio yang menunjukkan kinerja BRIS yang lebih baik dari sebelum terdaftar di BEI dengan nilai rata-rata sesudah terdaftar di BEI sebesar 29.16\%. Peningkatan rasio CAR artinya bahwa semakin baik penyediaan modal oleh BRIS untuk menutupi risiko yang mungkin timbul dari penanaman dana dalam aktivaaktiva produktif yang mengandung risiko serta untuk membiayai penanaman dalam aktiva tetap dan inventaris.

Rasio risk profile (NPF dan FDR) dan rasio rentabilitas(ROA dan NOM) menunjukkan kinerja BRIS yang tidak lebih baik jika dibandingkan dari sebelum terdaftar di BEI. Rasio NPF BRIS mengalami peningkatan sebesar $0.46 \%$ dari sebelum terdaftar di BEI menjadi sebesar $5.71 \%$ sesudah terdaftar di BEI. Peningkatan rasio NPF artinya tingkat permasalahan pembiayaan yang dihadapi oleh BRIS semakin meningkat sehingga kualitas pembiayaan BRIS lebih buruk dari sebelum terdaftar di BEI. Peningkatan rasio FDR menunjukkan bahwa kemampuan BRIS dalam memenuhi kewajiban jangka pendeknya pada saat ditagih semakin rendah atau dengan kata lain tingkat likuiditas BRIS sesudah terdaftar di BEI semakin menurun. Rasio ROA BRIS menurun sebesar 0.09\% sehingga menjadi $0.64 \%$ sesudah terdaftar di BEI. Penurunan rasio ROA sesudah terdaftar di BEI mengindikasikan berkurangnya kemampuan manajemen BRIS dalam mengelola aktiva untuk menekan biaya atau menghasilkan laba. Penurunan rasio NOM seiring dengan penurunan ROA, hal ini menandakan bahwa secara rentabilitas (earnings) kinerja BRIS dalam menghasilkan laba dari aktiva produktifnya menurun jika dibandingkan sebelum terdaftar di BEI. Berdasarkan data tersebut BRIS harus lebih baik lagi dalam mengelola pembiayaannya sehingga dikemudian hari tidak mengakibatkan peningkatan jumlah pembiayaan bermasalah dan manajemen harus memperbaiki pengelolaan aktiva yang dimiliki sehingga dapat meningkatkan laba yang dihasilkan.

\section{Tingkat Kesehatan Bank Tabungan Pensiunan Negara Syariah (BTPNS)}

Tabel 12

Tingkat Kesehatan BTPNS Sebelum Terdaftar di BEI 


\begin{tabular}{|c|c|c|c|c|c|c|}
\hline \multirow{2}{*}{ BTPNS } & \multicolumn{6}{|c|}{ SEBELUM } \\
\hline & Q2-2017 & Q3-2017 & Q4-2017 & Q1-2018 & Rata-rata & Peringkat \\
\hline \multicolumn{7}{|l|}{ RISK PROFILE } \\
\hline NPF & $1.70 \%$ & $1.66 \%$ & $1.67 \%$ & $1.67 \%$ & $1.68 \%$ & 1 \\
\hline FDR & $96.82 \%$ & $93.31 \%$ & $92.50 \%$ & $93.21 \%$ & $93.96 \%$ & 3 \\
\hline GCG & 2 & 2 & 2 & 2 & 2 & 2 \\
\hline \multicolumn{7}{|l|}{ EARNINGS } \\
\hline $\mathrm{ROA}$ & $10.38 \%$ & $10.74 \%$ & $11.19 \%$ & $12.49 \%$ & $11.20 \%$ & 1 \\
\hline NOM & $11.98 \%$ & $12.29 \%$ & $12.69 \%$ & $13.79 \%$ & $12.69 \%$ & 1 \\
\hline \multicolumn{7}{|l|}{ CAPITAL } \\
\hline CAR & $24.76 \%$ & $27.26 \%$ & $28.91 \%$ & $27.74 \%$ & $27.17 \%$ & 1 \\
\hline \multicolumn{6}{|c|}{ TINGKAT KESEHATAN BANK } & 2 \\
\hline
\end{tabular}

Sumber: Data diolah (2019)

Hasil perhitungan tingkat kesehatan BTPNS sebelum terdaftar di BEI mendapatkan peringkat komposit 2 seperti terlihat dari Tabel 12. Peringkat Komposit (PK-2) mencerminkan kondisi Bank yang secara umum sehat sehingga dinilai sangat mampu menghadapi pengaruh negatif yang signifikan dari perubahan kondisi bisnis dan faktor eksternal lainnya. Rata-rata rasio NPFsebelum terdaftar di BEI menunjukkan nilai sebesar $1.68 \%$ atau berada pada peringkat 1, yang artinya kualitas penerapan manajemen risiko kredit sangat memadai, meskipun terdapat kelemahan tapi kelemahan tersebut tidak signifikan sehingga dapat diabaikan. Rasio FDR BTPNS yang mencerminkan risiko likuiditas menunjukkan nilai rata-rata FDR sebesar $93.96 \%$ yang dikategorikan ke dalam peringkat 3, yang artinya tingkat manajemen risiko likuiditas BTPNScukup memadai, sehingga terdapat beberapa kelemahan yang membutuhkan perhatian manajemen. Faktor GCG BTPNS berada pada peringkat 2, hal ini mencerminkan manajemen BTPNS telah melakukan penerapan GCG yang secara umum cukup baik, dimana pemenuhan atas prinsip-prinsip Good Corporate Governance memadai. Rasio rentabilitas BTPNS dilihat dari ROA sebesar $11.20 \%$ atau dikategorikan dalam peringkat 1 yang artinya keberhasilan manajemen dalam menghasilkan laba sangat memadai, dimana laba melebihi target dan mendukung pertumbuhan permodalan bank.Rasio rentabilitas BTPNS dilihat dari NOM berada dalam peringkat 1 yang artinya kemampuan aktiva produktif dalam menghasilkan laba sangat memadai. Rasio permodalan BTPNS yang dilihat dari rasio CAR berada pada peringkat 1 yang artinya BTPNS memiliki kualitas dan kecukupan permodalan yang sangat memadai.

Tabel 13

Tingkat Kesehatan BTPNS Sesudah Terdaftar di BEI

\begin{tabular}{|c|c|c|c|c|c|c|}
\hline \multirow{2}{*}{ BT'PNS } & \multicolumn{6}{|c|}{ SESUDAH } \\
\hline & Q2-2015 & Q3-2015 & $\mathrm{Q} 42015$ & Q1-2019 & Rata-rata & Peringkat \\
\hline \multicolumn{7}{|l|}{ FISK PROFILE } \\
\hline NPF & $1.65 \%$ & $1.56 \%$ & $1.39 \%$ & $1.38 \%$ & $1.50 \%$ & 1 \\
\hline FDR & $97.89 \%$ & $96.03 \%$ & $95.60 \%$ & $96.03 \%$ & $96.39 \%$ & 3 \\
\hline GCG & 2 & 2 & 2 & & 2 & 2 \\
\hline \multicolumn{7}{|l|}{ EARNINGS } \\
\hline $\mathrm{ROA}$ & $12.54 \%$ & $1239 \%$ & $1237 \%$ & $1268 \%$ & $12.50 \%$ & 1 \\
\hline $\mathrm{NOM}$ & $13.83 \%$ & $13.62 \%$ & $13.61 \%$ & $13.87 \%$ & $13.73 \%$ & 1 \\
\hline \multicolumn{7}{|l|}{ CAPITAL } \\
\hline CAK & $36.90 \%$ & $3969 \%$ & $40.92 \%$ & $39.34 \%$ & $39.21 \%$ & 1 \\
\hline \multicolumn{6}{|c|}{ 'TINGKAT KESEHATAN BANK } & 2 \\
\hline
\end{tabular}


Tabel 13 menunjukkan tingkat kesehatan BTPNS sesudah terdaftar di BEI tetap berada pada peringkat komposit2(PK-2), masih sama seperti sebelum terdaftar di BEI. Berdasarkan Tabel12 dan Tabel 13 tersebut terlihat bahwa semua indikator tingkat kesehatan BTPNS sesudah terdaftar di BEI tidak mengalami perubahan, semua rasio baik NPF, FDR, GCG, ROA, NOM dan CAR berada pada peringkat yang sama seperti sebelum terdaftar di BEI. Dari data tersebut dapat disimpulkan bahwa BTPNS sudah menunjukkan kinerja yang baik dari sebelum terdaftar di BEI khususnya dalam mengelola risiko pembiayaan (NPF), GCG, rentabilitas (ROA, NOM), dan permodalan perusahaan (CAR), namun secara likuiditas (FDR) BTPNS belum melakukan perbaikan yang signifikan atas kelemahan manajemen risiko likuiditas yang membutuhkan perbaikan, hal ini ditunjukkan dengan peringkat FDR yang masih berada di peringkat 3 .

Membandingkan Tabel 12 dan Tabel 13diperoleh databahwa dilihat dari peringkat komposit (PK) tingkat kesehatan BTPNS sebelum dan sesudah terdaftar di BEI menunjukkan peringkat yang sama, yaitu pada peringkat komposit 2 (PK-2).Namun, jika menganalisa lebih detail atas rasio-rasio pembentuk tingkat kesehatan BTPNS, ada beberapa rasio yang mengalami kinerja yang lebih baik dari sebelum terdaftar di BEI, rasio tersebut antara lain rasio risk profile yang dilihat dari NPF, rasio rentabilitas yang dilihat berdasarkan rasio ROA dan NOM serta rasio permodalan BTPNS yang dilihat dari rasio CAR. NPF, ROA,NOM, dan CAR secara berturut-turut mengalami kenaikan kinerja sebesar $0.18 \%, 1.3 \%, 1.04 \%$, dan $12.04 \%$ jika dibandingkan sebelum terdaftar di BEI, sehingga masing-masing nilai rasio sesudah terdaftar di BEI secara berturut -turut menjadi sebesar $1.5 \%, 12.5 \%, 13.73 \%$ dan 39,21\%.

Sementara rasio risk profile BTPNS lainnya yaitu FDR menunjukkan kinerja yang tidak lebih baik dari sebelum terdaftar di BEI. Rasio FDR sesudah terdaftar di BEI sebesar $96.39 \%$ dimana terdapat peningkatan rasio FDR sebesar $2.43 \%$ dari sebelum terdaftar di BEI. Peningkatan pada rasio FDR bermakna bahwa kemampuan bank dalam membayar kembali penarikan dan yang dilakukan oleh para deposan dengan mengandalkan pembiayaan yang diberikan sebagai sumber likuiditasnya. Untuk itu, manajemen BTPNS perlu memperbaiki pengelolaan risiko likuiditasnya agar tidak menjadi semakin memburuk.

\section{PEMBAHASAN}

\section{Perbandingan Tingkat Kesehatan BRIS dan BTPNS Sebelum dan Sesudah Terdaftar di BEI}

Tabel 14

Tingkat Kesahatan BRIS dan BTPNS 


\begin{tabular}{|c|c|c|c|c|c|c|c|c|}
\hline \multirow{3}{*}{$\begin{array}{c}\text { INDIKATOR } \\
\text { RBBR }\end{array}$} & \multicolumn{4}{|c|}{ SEBELUM } & \multicolumn{4}{|c|}{ SESUDAH } \\
\hline & \multicolumn{2}{|c|}{ BRIS } & \multicolumn{2}{|c|}{ BTPNS } & \multicolumn{2}{|c|}{ BRIS } & \multicolumn{2}{|c|}{ BTPNS } \\
\hline & RASIO & PERINGKAT & RASIO & PERINGKAT & RASIO & PERINGKAT & RASIO & PERINGKAT \\
\hline \multicolumn{9}{|l|}{ RISK PROFILE } \\
\hline NPF & $5.25 \%$ & 3 & $1.68 \%$ & 1 & $5.71 \%$ & 3 & $1.50 \%$ & 1 \\
\hline FDR & $72.62 \%$ & 1 & $93.96 \%$ & 3 & $77.31 \%$ & 2 & $96.39 \%$ & 3 \\
\hline GCG & 2 & 2 & 2 & 2 & 2 & 2 & 2 & 2 \\
\hline \multicolumn{9}{|l|}{ EARNINGS } \\
\hline $\mathrm{ROA}$ & $0.73 \%$ & 3 & $11.20 \%$ & 1 & $0.64 \%$ & 3 & $12.50 \%$ & 1 \\
\hline NOM & $0.19 \%$ & 5 & $12.69 \%$ & 1 & $-0.18 \%$ & 5 & $13.73 \%$ & 1 \\
\hline \multicolumn{9}{|l|}{ CAPITAL } \\
\hline CAR & $21.34 \%$ & 1 & $27.74 \%$ & 1 & $29.16 \%$ & 1 & $39.21 \%$ & 1 \\
\hline & & PK-3 & & PK-2 & & PK-3 & & PK-2 \\
\hline
\end{tabular}

Sumber: Data diolah (2019)

Berdasarkan Tabel 14 di atas terlihat bahwa tingkat kesehatan BTPNS sebelum dan sesudah terdaftar di BEI berada pada peringkat komposit 2 (PK-2) lebih baik dibandingkan tingkat kesehatan BRIS yang berada pada peringkat komposit 3 (PK-3).BTPNS lebih baik atas BRIS terutama untuk rasio NPF, ROA dan NOM, dimana untuk ketiga rasio tersebut BTPNS berada pada peringkat 1 yang artinya BTPNS sudah sangat memadai dalam mengelola risikopembiayaan (NPF) dan dari faktor rentabilitas (ROA dan NOM)BTPNS sudah sangat memadai dalam mengelola risiko dan mengelola pencapaian laba.

BRIS menunjukkan kinerja lebih baik dari BTPNS jika dilihat dari risiko likuiditas (FDR), dimana BRIS berada pada peringkat 1 sebelum terdaftar di BEI dan berada pada peringkat 2 sesudah terdaftar di BEI. Meskipun peringkat FDR BRIS turun sesudah terdaftar di BEI yaitu menjadi peringkat 2, namun peringkat FDR BRIS tetap lebih baik dari BTPNS yang berada pada peringkat 3 baik sebelum maupun sesudah terdaftar di BEI. Hal ini menjadi catatan peneliti mengingat dari enam indikator RBBR yang digunakan peneliti untuk menilai tingkat kesehatan bank hanya indikator FDR yang belum menunjukkan kinerja maksimal BTPNS. Peringkat likuiditas BTPNS ini sebaiknya menjadi perhatian manajemen untuk mulai mengidentifikasi kelemahan yang mungkin ada sehingga bisa dilakukan perbaikan (corrective action).

BRIS dan BTPNS menunjukkan kinerja yang sama jika dilihat dari indikator GCG dan permodalan (CAR).Seperti terlihat pada Tabel 14 peringkat GCG BRIS dan BTPNS berada pada peringkat 2 baik sebelum maupun sesudah terdaftar di BEI, yang artinya manajemen BRIS dan BTPNS sudah melakukan penerapan GCG yang baik. Dari faktor permodalan yang ditinjau dari rasio CAR terlihat bahwa baik BRIS maupun BTPNS menunjukkan peningkatan rasio CAR dari sebelum terdaftar di BEI. Peningkatan rasio CAR BRIS sebesar $7.82 \%$ dari sebelum terdaftar di BEI, sehingga sesudah terdaftar di BEI CAR BRIS menjadi sebesar 29.16\%. Sementara itu peningkatan CAR BTPNS sebesar $11.47 \%$ dari sebelum terdaftar di BEI, sehingga rasio CAR BTPNS menjadi sebesar 39.21\%. Meskipun rasio CAR BRIS dan BTPNS sama-sama mengalami peningkatan, 
namun peningkatan rasio CAR BTPNS lebih besar dibandingkan peningkatan CAR yang dicapai BRIS.

\section{KESIMPULAN}

Berdasarkan hasil analisis tingkat kesehatan BRIS dan BTPNS sebelum dan sesudah terdaftar di BEI dengan menggunakanaspek kuantitatif dari metode RBBR yaitu menggunakan rasio NPF, FDR, ROA, NOM dan CAR serta hasil self-assessment GCG yang sudah dipublikasi, diperoleh kesimpulan sebagai berikut:

Tingkat kesehatan BRIS dan BTPNS sesudah terdaftar di BEI dilihat dari peringkat komposit kesehatan bank tidak menunjukkan perbedaan jika dibandingkan dengan sebelum terdaftar di BEI yaitu berada pada peringkat komposit 3 (PK-3) untuk BRIS dan peringkat komposit 2 (PK-2) untuk BTPNS. PK-3 artinya BRIS dikategorikan kedalam bank yang cukup sehat dan BTPNS dikategorikan kedalam bank yang sehat (PK-2).

Penilaian tingkat kesehatan BRIS dan BTPNS dilihat dari faktor risk profile, yaitu NPF dan FDR menunjukkan bahwa NPF dan FDR BRIS sesudah terdaftar di BEI tidak lebih baik dibandingkan sebelum terdaftar di BEI. Hal ini terlihat dari rasio NPF dan FDR yang semakin tinggi bahkan FDR BRIS mengalami penurunan peringkat dari peringkat 1 sebelum terdaftar di BEI menjadi peringkat 2 sesudah terdaftar di BEI. Sementara NPF dan FDR BTPNS meskipun tidak mengalami perubahan peringkat tapi secara rasio mengalami penurunan, yang artinya tingkat kesehatan BTPNS sesudah terdaftar di BEI dilihat dari NPF dan FDR semakin membaik jika dibandingkan dengan sebelum terdaftar di BEI.

Penilaian tingkat kesehatan BRIS dan BTPNS dilihat dari faktor GCG tidak menunjukkan perubahan yaitu tetap pada peringkat 2, yang artinya manajemen BRIS dan BTPNS telah melakukan penerapan GCG yang secara umum baik.

Penilaian tingkat kesehatan BRIS sesudah terdaftar di BEI dilihat dari faktor rentabilitas, yaitu ROA dan NOM menunjukkan rasio yang lebih kecil dibandingkan sebelum terdaftar di BEI meskipun secara peringkat tidak menunjukkan perubahan. Yang perlu menjadi catatan adalah NOM BRIS berada pada peringkat 5 yang artinya berada pada posisi yang tidak memadai untuk aktiva produktif menghasilkan laba, kondisi ini harus segera diperbaiki oleh manajemen BRIS. Tingkat kesehatan BTPNS dilihat dari ROA dan NOM tidak menunjukkan perubahan dari sebelum terdaftar di BEI yaitu berada pada peringkat 1, yang artinya rentabilitas BTPNS sangat memadai dimana laba melebihitarget dan mendukung pertumbuhan permodalan bank.

Penilaian tingkat kesehatan BRIS dan BTPNS sesudah terdaftar di BEI yang dilihat dari faktor permodalan menunjukkan rasio CAR yang semakin meningkat dari sebelum terdaftar di BEI, meskipun secara peringkat tidak ada perubahan yaitu berada pada peringkat 1 yang artinya BRIS dan BTPNS memiliki kualitas dan kecukupan permodalan yang sangat memadai terhadap profil risikonya.

Keterbatasan dalam penelitian ini tidak adanya kodifikasi yang dikeluarkan oleh OJK terkait penilaian tingkat kesehatan bank sehingga peneliti masih menggunakan 
kodifikasi yang dikeluarkan oleh Bank Indonesia tahun 2012.Penelitian ini juga tidakmelakukan analisa atas profil risiko imbal hasil dan risiko investasi yang merupakan risiko yang membedakan bank syariah dengan bank konvensional. Untuk penelitian selanjutnya terkait tingkat kesehatan bank syariah disarankan untuk menyertakan risiko imbal hasil dan risiko investasi sebagai indikator/parameter yang dianalisis.

\section{REFERENSI}

Bank Indonesia. (2012). Kodifikasi Peraturan Bank Indonesia Kelembagaan Penilaian Tingkat Kesehatan Bank. Jakarta: Pusat Riset dan Edukasi Bank Sental.

Harahap, S.S., Wiroso, \& Yusuf, M. (2010). Akuntansi Perbankan Syariah.Jakarta:LPFE Usakti

Pambudi, S., Darmawan, A. (2018). Analisis Kinerja Bank Umum Syariah dengan Metode Risk Based Bank Rating (RBBR) untuk Mengetahui Tingkat Kesehatan Bank. Jurnal Administrasi dan Bisnis, 56 (1), 127-136.

Penjelasan POJK Nomor 8/POJK.03/2014 Tentang Penilaian Tingkat Kesehatan Bank Umum Syariah dan Unit Usaha Syariah

Peraturan Otoritas Jasa Keuangan Nomor 8/POJK.03/2014 Tentang Penilaian Tingkat Kesehatan Bank Umum Syariah dan Unit Usaha Syariah

SE OJK Nomor 10/SEOJK.03/2014 Tentang Penilaian Tingkat Kesehatan Bank Umum Syariah dan Unit Usaha Syariah

Suhartono, et.al.(2017). Analisis Tingkat Kesehatan Bank dengan Menggunakan Metode Risk Based Bank Rating (Studi pada Bank Milik Pemerintah Pusat yang Terdaftar di Bursa Efek Indonesia Tahun 2012-2015). Jurnal Administrasi Bisnis, 46 (1), 131-139

Undang-undang Nomor 10 Tahun 1998 tentang Perbankan

Undang-undang Nomor 21 Tahun 2008 tentang Perbankan Syariah

Yaya, R.., Martawireja, A.E., \& Abdurahim, A. (2018). Akuntansi Perbankan Syariah. Jakarta: Salemba Empat 